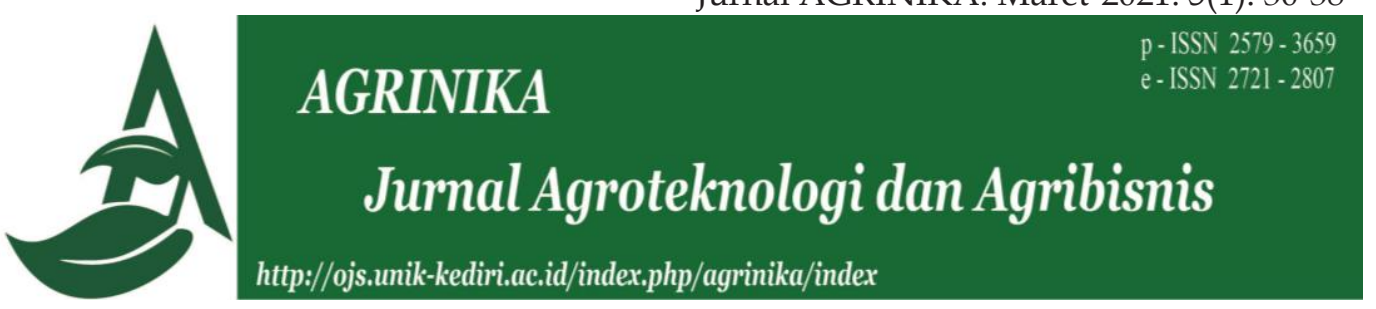

\title{
Pengaruh Motivasi, Lingkungan dan Pengalaman Pemuda Tani dalam Melanjutkan Usahatani Kopi di Desa Kelurahan Kecamatan Jambu Kabupaten Semarang
}

\author{
Fadhlan Jamil Putra $^{1^{*}}$, Tutik Dalmiyatun ${ }^{1}$, Agus Subhan Prasetyo ${ }^{1}$ \\ ${ }^{1}$ Program Studi Agribisnis, Departemen Pertanian, Fakultas Peternakan dan \\ Pertanian, Universitas Diponegoro, Semarang, Indonesia \\ *Korespondensi: fadlanjamil30@gmail.com
}

Diterima 18 Desember 2020/Direvisi 17 Februari 2021/Disetujui 23 Februari 2021

\begin{abstract}
ABSTRAK
Kelompok tani rahayu memiliki harapan kepada pemuda di Desa Kelurahan untuk melanjutkan dan mengembangkan usahatani kopi atas keinginannya sendiri. Penelitian ini bertujuan untuk menganalisis minat pemuda pedesaan dalam melanjutkan usahatani kopi di Desa Kelurahan, Kecamatan Jambu, Kabupaten Semarang, menganalisis faktor yang mempengaruhi pemuda desa dalam melanjutkan usahatani, dan menganalisis pengaruh faktor motivasi, pengalaman, lingkungan terhadap minat pemuda dalam melanjutkan usahatani. Desa Kelurahan dipilih sebagai lokasi penelitian didasarkan pada pertimbangan bahwa Desa Kelurahan memiliki kelompok tani yang mengembangkan agrowisata. Jumlah sampel ditentukan dari pemuda yang orang tuanya tergabung di kelompok tani rahayu sebanyak 39 pemuda sebagai responden, sedangkan penentuan sampel dilakukan dengan menggunakan sensus. Pengumpulan data dilakukan dengan melakukan wawancara berdasarkan kuesioner yang telah dipersiapkan. Data dianalisis menggunakan regresi linear berganda. Hasil diketahui bahwa motivasi merupakan variabel yang paling berpengaruh terhadap minat pemuda di kelompok tani rahayu. Pengalaman dan lingkungan memiliki pengaruh terhadap minat pemuda. Minat pemuda akan timbul ketika motivasi, pengalaman dan lingkungan mendukung pemuda dalam melanjutkan usahatani.
\end{abstract}

Kata kunci : Kelompok tani; Minat pemuda; Usahatani kopi

\section{ABSTRACT}

Tani Rahayu farmer group hopes that the youth in the Kelurahan Village will continue and develop coffee farming on their own accord. A study aimed to analyze the interest of rural youth in continuing coffee farming in the Kelurahan Village, Jambu District, Semarang Regency, to analyze the factors that influence rural youth in continuing coffee farming, and to analyze the influence of motivation, experience, and environmental factors on youth interest in continuing coffee farming. The Kelurahan Village were chosen as research location based on the consideration that the farmer groups in Kelurahan Villages have developed an agritourism. The number of samples was determined by census from the youth whose parents were members of the Tani Rahayu farmer group as many as 39 youths. Data collection was carried out by conducting interviews based on a prepared questionnaire. Data were analyzed using multiple linear regression. The results showed that motivation is the variable that most influenced the youth's interest in Tani Rahayu farmer groups. Experience and the environment influence youth interests as well. 
Fadlan Jamil Putra, Pengaruh Motivasi, Lingkungan...

Youth interest will arise when motivation, experience, and environment support youth in continuing coffee farming.

Keywords: Farmer group; Youth interest; Coffee farming

\section{PENDAHULUAN}

Kopi adalah komoditas ekspor yang diunggulan pada bidang perkebunan yang mempunyai peran yang penting dalam perdagangan dan perekonomian negara dikarenakan salah satu penyumbang devisa negara (Thamrin, 2016). Berdasarkan Badan Pusat Statistik (2019) bahwa nilai ekspor kopi Indonesia pada tahun 2014 sampai 2018 sebesar 409,86 ton. Namun, dalam jangka waktu 5 tahun terakhir Indonesia mengalami fluktuasi dalam mengekspor kopi, padahal Indonesia memiliki potensi dikarekan meingkatnya permintaan kopi di dunia. Menurut Baso dan Anindita (2018) Indonesia merupakan salah satu negara penghasil kopi terbesar yaitu keempat di dunia setelah negara Brazil, Kolombia dan Vietnam.

Pada tahun 2010 rata-rata produktivitas kopi di Indonesia mencapai $700 \mathrm{~kg}$ biji kering per hektar per tahun (Suwandari \& Soetriono, 2010). Produktivitas kopi di Indonesia yang cukup tinggi didukung oleh produktivitas kopi dari berbagai daerah salah satunya yaitu Jawa Tengah. Provinsi Jawa Tengah turut andil dalam memenuhi kebutuhan kopi nasional maupun dunia, dimana salah satu Kabupaten yang menghasilkan kopi yaitu Kabupaten Semarang. Penghasil kopi terbesar di Kabupaten Semarang berada di Kecamatan Jambu.

Kopi merupakan komoditas unggulan di Kecamatan Jambu. Jenis produksi kopi yang dihasilkan di
Kecamatan Jambu yaitu kopi robusta dan kopi arabika. Tahun 2017 Kecamatan Jambu memproduksi kopi mencapai 467,86 ton atau $35,36 \%$ produksi kopi yang ada di Kabupaten Semarang (Badan Pusat Statistik, 2018).

Kelompok Tani adalah lembaga pertanian yang terbentuk karena memiliki tujuan dan kebutuhan untuk meningkatkan dan mengembangkan usaha (Prasetyo et al., 2020). Kelompok Tani Rahayu 2, 3 dan 4 merupakan kelompok yang menyumbang produksi kopi terbesar di Desa Kelurahan. Desa Kelurahan memiliki keunggulan dibandingkan dari desa yang lain yaitu mampu membangun tempat wisata kopi yang dinamakan Kopi Dusun Sirap. Keunggulan lainnya yaitu desa tersebut memiliki pemuda yang memiliki kemampuan dalam mengolah olahan kopi. Akan tetapi, kemampuan tersebut berbanding terbalik dengan minat pemuda yang tidak memiliki ketertarikan untuk bekerja di sektor perkebunan kopi. Menurut (Arvianti \& et al., 2015) menyatakan bahwa minat merupakan suatu ketertarikan seseorang untuk mengembangkan usahatani kopi.

Kondisi lain menunjukkan bahwa orang tua memiliki harapan pada pemuda untuk dapat melanjutkan usahatani kopi milik keluarga mereka masing-masing, mengingat umur orang tua yang sudah berusia lanjut. Maka, minat pemuda dalam melanjutkan usahatani kopi sangat diperlukan karena jika minat pemuda dalam melanjutkan usahatani kopi terus menurun maka 
keberlanjutan usahatani kopi dapat terancam. Padahal pemuda sangat dibutuhkan dalam mengembangkan usahatani kopi. Menurut (Mutlik, 2011), menyatakan bahwa pemuda memiliki peranan penting dalam pembangunan sumber daya manusia yang baik untuk menggantikan generasi yang sudah berumur. Sehingga, peneliti tertarik untuk melakukan penelitian mengenai minat pemuda desa dalam melanjutkan usahatani kopi.

Tujuan penelitian ini adalah (i) menganalisis minat pemuda pedesaan dalam melanjutkan usahatani kopi di Desa Kelurahan, Kecamatan Jambu, Kabupaten Semarang, (ii) menganalisis faktor yang mempengaruhi pemuda desa dalam melanjutkan usahatani (iii) menganalisis pengaruh faktor motivasi, pengalaman, lingkungan terhadap minat pemuda dalam melanjutkan usahatani. Manfaat penelitian ini adalah bagi pemerintah sebagai bahan masukan dan pertimbangan dalam menyusun kebijakan, bagi petani mengetahui apa yang membuat pemuda pedesaan ingin meneruskan usahatani.

\section{METODE PENELITIAN}

Penelitian ini dilaksanakan pada Juli 2020 - Agustus 2020 di Desa Kelurahan, Kecamatan Jambu, Kabupaten Semarang. Penentuan lokasi ditentukan secara purposive dengan pertimbangan bahwa lokasi penelitian merupakan desa yang maju dalam mengembangkan kopi dengan membuat agrowisata di Desa Kelurahan, Kecamatan Jambu.

Data yang digunakan dalam penelitian ini adalah data primer dan data sekunder. Data primer merupakan kegiatan wawancara dengan menggunakan kuesioner kepada responden dengan mengamati dan observasi langsung. Data sekunder didapat dari dokumentasi Desa Kelurahan mengenai keadaan umum dan juga Kelompok Tani Rahayu. Pengumpulan data yang dilakukan peneliti dengan melalui kuesioner sekaligus wawancara langsung, observasi langsung dan dokumentasi dengan para responden.

Penelitian ini menggunakan metode analisis deskriptif dan statistik. Analisis deskriptif merupakan metode analisis yang dilakukan dengan menjabarkan atau memaparkan jawaban dari responden (Kurniawan \& Yuniarto, 2016). Analisis statistik yang digunakan adalah Regresi Linier Berganda.

Penentuan sampel penelitian yang digunakan dengan pengambilan sampel secara sensus. Metode penelitian secara sensus yaitu penelitian menggunakan metode mengambil sampel dalam suatu kelompok dengan menggunakan kuisioner sebagai alat bantu untuk mendapatkan data dan informasi. Jumlah responden yang diwawancarai sebanyak 39 responden dengan pemuda yang orang tuanya bekerja sebagai petani kopi dan tergabung di kelompok tani Rahayu 2, 3 dan 4 yang dijadikan sebagai responden.

Analisis yang digunakan dalam peneltian ini yaitu regresi linier berganda untuk mengetahui pengaruh motivasi, pengalaman dan lingkungan terhadapt minat pemuda dalam melanjutkan usatahani, dengan menggunakan SPSS, persamaan dari regresi berganda sebagai berikut:

$$
\begin{aligned}
& Y=a+b_{1} X_{1}+b_{2} X_{2}+b_{3} X_{3}+e_{i} \\
& \text { Dimana }: Y=\text { Minat Pemuda } \\
& \mathrm{X}_{1}=\text { Motivasi } \\
& \mathrm{X}_{2} \quad=\text { Lingkungan }
\end{aligned}
$$




$$
\begin{aligned}
& \mathrm{X}_{3} \quad=\text { Pengalaman } \\
& \text { a } \quad=\text { Konstanta } \\
& \mathrm{e}_{\mathrm{i}} \quad=\text { Konstanta pengganggu }
\end{aligned}
$$

\section{HASIL DAN PEMBAHASAN}

Keadaan Desa Kelurahan

Desa Kelurahan adalah desa yang terletak di Kabupaten Semarang Provinsi Jawa Tengah, di antara 7, 2884 Bujur Timur dan 110,3641 Lintang Selatan (BPS, 2015). Desa Kelurahan memiliki delapan dusun, antara lain : Dusun Sirap, Kelurahan, Candisari, Tempuran, Sesel, Kaligaleh, Tapak dan Kalimalang dengan luas Desa keseluruhan yaitu 3,79 Km2. Masyarakat Desa Kelurahan masih tergantung pada perkebunan kopi dimana masyarakat yang bekerja di perkebunan kopi yang paling dominan. Desa Kelurahan memiliki tiga Kelompok Tani yaitu Kelompok Tani Rahayu 2, 3 dan 4.

\section{Kelompok Tani Rahayu} merupakan kelompok tani yang ada di Desa Kelurahan. Kelompok tani Rahayu memiliki anggota sebanyak 90 orang, memiliki luas lahan budidaya kopi kurang lebih 80 ha. Kelompok Tani Rahayu memiliki potensi di bidang perkebunan kopi dikarenakan Kelompok Tani Rahayu memiliki kafe yang berada di Dusun Sirap. Kafe Dusun Sirap yang berada di ketinggian 600-1.050 meter dpl dengan dikelilingin bukit hingga belerang.

Kafe Dusun Sirap merupakan agrowisata yang memanfaatkan keindahan alam di tengah-tengah perkebunan kopi. Kafe Dusun Sirap tidak hanya memberikan produk olahan kopi tetapi keindahan alam yang sejuk di pandang mata dan memiliki makanan khasdari Desa Kelurahan. Kafe Dusun Sirap juga bisa belajar tentang budidaya kopi, sortir, penyangraian hingga kopi menjadi bubuk dan pengemasan. Kopi Dusun Sirap juga disebut juga agrowisata yang mengedukasi konsumen.

\section{Minat Pemuda}

Minat pemuda merupakan suatu keinginan pemuda dalam melakukan sesuatu. Penelitian ini menganalisis tingkat minat pemuda melanjutkan usahatani kopi. Petani berharap pemuda di kelompok tani rahayu bisa melanjutkan dan mengembangkan kopi di Desa Kelurahan. Berdasarkan nilai frekuensi dan persentase variabel minat pemuda dapat dilihat pada tabel 1 .

Tabel 1. Minat pemuda di kelompok tani rahayu dalam melanjutkan usahatani kopi di Desa Kelurahan, tahun 2020.

\begin{tabular}{lcc}
\hline \multicolumn{1}{c}{ Kategori } & Frekuensi (orang) & Persentase (\%) \\
\hline Tinggi & 29 & 74,4 \\
Rendah & 10 & 25,6 \\
\hline Jumlah & 39 & 100 \\
\hline
\end{tabular}

Sumber : Data primer penelitian diolah, 2020.

Persentase minat pemuda dalam melanjutkan usahatani kopi termasuk dalam kategori yang tinggi. Pemuda selalu termotivasi dalam mengem- bangkan usahatani kopi di Desa Kelurahan, dikarekan Desa Kelurahan memiliki potensi berupa agrowisata kopi yang mengajarkan dalam budidaya kopi. 
dalam perkebunan kopi. Pemuda yang memiliki pengalaman di bidang perkebunan kopi selalu bekerjasama untuk memberikan hal baru kepada petani kopi. Pemuda yang melanjutkan usahatani kopi memiliki inovasi seperti membuat olahan kopi yang berbeda dengan kopi lain yaitu kopi jahe. Hal ini membuat Desa Kelurahan sudah maju dari desa lainnya yang berada di Kecamatan Jambu.

Faktor yang Mempengaruhi Minat Pemuda

\section{Motivasi Pemuda}

Motivasi pemuda merupakan variabel yang memiliki nilai tinggi pada penelitian ini dengan persentase $82 \%$. Kondisi ini disebabkan bahwa kedua orang tua pemuda selalu memberikan motivasi, sehingga pemuda memiliki keinginan untuk melanjutkan usahatani kopi dan juga para orang tua men- dukung pemuda Desa Kelurahan dalam mengembangkan usahatani kopi. Pendapat Ardini (2010) yang menyatakan bahwa seseorang perlu diberikan bimbingan dalam mengambil langkah-langkah untuk mencapai kesuksesan dan kekuatan atau keadaan sehingga mendorong individu untuk mencapai tujuannya. Responden penelitian akan dianalisis tingkat motivasi, pengalaman dan lingkungan pemuda terhadap minat pemuda. Sehingga, penelitian yang sudah dilakukan didapatkan nilai frekuensi dan persentase variabel motivasi, pengalaman dan lingkungan pemuda dapat dilihat pada tabel 2 .

Hasil penelitian menunjukkan bahwa motivasi yang diberikan kepada pemuda tertinggi dari variabel lainnya. Kondisi ini menunjukkan bahwa pemuda tani memiliki motivasi yang tinggi.

Tabel 2. Motivasi pemuda di kelompok tani rahayu dalam melanjutkan usahatani kopi di Desa Kelurahan, tahun 2020.

\begin{tabular}{clcc}
\hline \hline No & \multicolumn{1}{c}{$\begin{array}{c}\text { Faktor yang } \\
\text { Mempengaruhi Minat Pemuda }\end{array}$} & $\begin{array}{c}\text { Skor rata-rata } \\
\text { Maks }\end{array}$ & Persentase \\
\hline 1 & Motivasi & 5 & 82 \\
2 & Pengalaman & 5 & 77 \\
3 & Lingkungan & 5 & 74 \\
\hline
\end{tabular}

Sumber : Data Primer Penelitian Diolah 2020.

Minat pemuda akan tinggi apabila keinginan dan kebutuhan pemuda yang menjadikan motivasi dalam bekerja dapat dipenuhi. Adanya motivasi yang baik terhadap suatu hal akan mendorong pemuda untuk melakukan perubahan perilaku, sehingga motivasi yang diberikan kepada pemuda memberikan manfaat yang akan menyebabkan mereka terdorong ingin melanjutkan usahatani kopi. Motivasi yang diberikan keluarga kepada anaknya sangat penting karena dapat membentuk tindakan pemuda dalam melakukan pekerjaan di bidang perkebunan kopi. Pendapat (Naashir et al., 2016) yang menyatakan bahwa motivasi adalah suatu dorongan secara pribadi dalam keadaan yang sadar dan berkeinginan mencapai tujuannya.

Motivasi yang sudah diberikan oleh orang tua kepada pemuda petani merupakan motivasi yang positif. Orang tua pemuda tani selalu memberikan bimbingan dalam mengambil langkahlangkah yang perlu dilakukan agar 
pemuda tani sukses dalam berusatani kopi. Pendapat tersebut sesuai dengan (Ardini, 2010), yang mengatakan seseorang perlu diberikan bimbingan dalam mengambil langkah-langkah untuk mencapai kesuksesan.

\section{Pengalaman Pemuda}

Pengalaman pemuda tentang usahatani kopi di kelompok tani rahayu termasuk dalam kriteria yang tinggi yang berarti bahwa pemuda memiliki pengalaman dalam berusahatani kopi. Hal ini dikarenakan sejak kecil pemuda di kelompok tani rahayu sudah berkecimpung di perkebunan kopi. Pengalaman merupakan pekerjaan yang telah dilakukan selama jangka waktu tertentu sehingga mempengaruhi keinginan seseorang terhadap yang dikerjakan (Porajouw et al., 2014). Pemuda yang memliki pengalaman dalam berusahatani perkebunan kopi melakukan pekerjaannya dengan baik dan terampil. Pendapat (Piran et al., 2019), yang menyatakan bahwa seseorang yang sudah memiliki pengalaman maka seseorang tersebut lebih memahami pekerjaan yang dia lakukan dibandingan seseorang yang belum memiliki pengalaman.

\section{Lingkungan Pemuda}

Tingkat persentase komponen lingkungan di sekitar pemuda tentang usahatani kopi di kelompok tani rahayu termasuk dalam kriteria yang tinggi. Faktor yang mempengaruhi minat seseorang yaitu salah satunya faktor lingkungan. Lingkungan terbagi menjadi dua antara lain, lingkungan keluarga dan lingkungan masyarakat. Menurut (Suhartini, 2011), menyatakan bahwa pendidikan utama yang diterima dari seseorang anak berasal dari keluarga. Hal ini menunjukkan keluarga sangat berperan dalam memberikan pengajaran dan mempengaruhi anak sehingga memiliki kreativitas dan tanggung jawab yang dapat ditumbuhkan sejak mulai berinteraksi dengan orang. Lingkungan yang daoat mempengaruhi seseorang karena masyarakat tempat tinggal mereka banyak yang bertani antara lain saudara, teman, tetangga, dan orang disekitar. Pemuda di kelompok tani rahayu memiliki lingkungan yang dapat mempengaruhi mereka dalam melanjutkan usahatani kopi.

\section{Hasil Uji Analisis Regresi Berganda}

Analisis data yang dilakukan dalam penelitian ini adalah untuk mengetahui dampak dari variabel terhadap minat pemuda di Kelompok Tani Rahayu.

Data yang telah dianalisis pada tabel menggunakan uji regresi linear berganda, dengan hasil persamaan $Y=$ $4.617+0.185 X_{1}+0.520 X_{2}+0.060 X_{3}+$ e. konstanta bernilai positif yaitu 4.617 menunjukkan bahwa dengan mengamsumsikan tidak adanya variabel independen, maka minat pemuda di Kelompok tani Rahayu lebih meningkat. Hasil uji regresi menunjukkan bahwa minat pemuda dengan motivasi, pengalaman dan lingkungan berbanding lurus. Nilai koefisien regresi pada variabel motivasi (X1), variabel pengalaman (X2) dan variabel lingkungan yaitu positif, hal ini menunjukkan bahwa apabila variabel motivasi mengalami peningkatan dengan anggapan variabel independen lain tetap maka minat pemuda mengalami peningkatan sebesar 0,185 (X1), 0.520 (X2), 0.060 (X3).

$\mathrm{Hal}$ ini menunjukkan bahwa motivasi yang diberikan kepada pemuda 
Tabel 3. Hasil analisis regresi linier berganda di kelompok tani rahayu dalam melanjutkan usahatani kopi di Desa Kelurahan, tahun 2020.

\begin{tabular}{lccc}
\hline \multirow{2}{*}{ Model } & \multicolumn{3}{c}{ Koefisien } \\
\cline { 2 - 4 } & \multicolumn{2}{c}{ Boefisien tidak Standar } & Koefisien Standar \\
\hline 1 (Constant) & 4.617 & Std. Error & Beta \\
Motivasi & 0.185 & 0.555 & 0.197 \\
Pengalaman & 0.520 & 0.154 & 0.495 \\
Lingkungan & 0.060 & 0.154 & 0.061 \\
\hline
\end{tabular}

Sumber : Data Primer Penelitian Diolah, 2020.

perkebunan kopi. Orang tua yang memberikan motivasi kepada anaknya akan dapat meningkatkan kepercayaan diri anaknya sehingga dapat melanjutkan usahatani kopi. Pendapat (Naashir et al., 2016), motivasi dapat ditingkatkan dari individu seseorang ataupun dari luar individu contohnya keluarga maupun teman.

Pemuda yang memiliki pengalaman dalam bidang perkebunan kopi akan lebih cepat mengerti dengan situasi pertanian yang ada di lingkungannya. Menurut (Arimbawa \& Rustariyuni, 2018) menyatakan bahwa pengalaman yang dimiliki pada bidang pertanian dapat menunjukan keberanian dalam mengembangkan tekonologi di bidang pertanian.

Lingkungan di sekitar pemuda mempunyai peranan penting dalam mewujudkan minat seseorang. Pendapat (Suparmini et al., 2013) menyatakan lingkungan memiliki peran besar dalam membentuk dan menumbuhkan watak seseorang.

\section{Koefisien Determinasi}

Berdasarkan hasil yang telah dilakukan diperoleh hasil sebagai berikut:

Tabel 4. Koefisien determinasi di kelompok tani rahayu dalam melanjutkan usahatani kopi di Desa Kelurahan, tahun 2020.

\begin{tabular}{ll}
\hline \hline Variabel & Adjusted R-square \\
\hline Motivasi (X1) & 0,352 \\
Pengalaman (X2) & \\
Lingkungan (X3) &
\end{tabular}

Sumber : Data Penelitian Diolah, 2020.

Berdasarkan Tabel 4 diperoleh hasil dari uji koefisien determinasi terdapat nilai adjusted $r$ square sebesar 0,352 yang berarti motivasi, pengalaman dan lingkungan berpengaruh $35,2 \%$ terhadap minat pemuda sisanya dipengarungi yang lain. Pendapat (Kurniawan \& Yuniarto, 2016) yang menyatakan bahwa nilai $R^{2}$ antara 0 - 1 dan kecocokan model dikatakan baik kalau $R^{2}$ semakin mendekati 1 . Pendapat tersebut didukung oleh (Majid, 2015) yang menyatakan bahwa $R^{2}$ untuk mengukur seberapa jauh kemampuan model dalam menerangkan variasi variabel terikat.

\section{KESIMPULAN}

Berdasarkan hasil penelitian dan pembahasan, dapat disimpukan bahwa :

1. Motivasi, pengalaman dan lingkungan sebagai faktor yang mempengaruhi minat pemuda dalam melanjutkan usatahani kopi termasuk kategori yang tinggi. 
2. Minat pemuda di Desa Kelurahan Kecamatan Jambu termasuk kategori tinggi. Hal ini dapat dilihat dari pemuda di Kelompok Tani Rahayu Desa Kelurahan memiliki keinginan untuk mengembangkan kopi dan juga dapat memajukan Kafe Dusun Sirap yang dibangun untuk diteruskan oleh pemuda.

3. Secara serempak dan parsial motivasi, pengalaman dan lingkungan berpengaruh terhadap minat pemuda di kelompok tani rahayu.

\section{DAFTAR PUSTAKA}

Ardini, L. (2010). Pengaruh Kompetensi, Independensi, Akuntabilitas Dan Motivasi Terhadap Kualitas Audit. Majalah Ekonomi Tahun XX, 3, 67.

Arimbawa, I. P. E., \& Rustariyuni, S. D. (2018). Respon Anak Petani Meneruskan Usaha Tani Keluarga Di Kecamatan Abiansemal. EJurnal EP Unud, 7(7), 1558-1586.

Arvianti, E. Y., \& et al. (2015). Minat Pemuda Tani Terhadap Transformasi Sektor Pertanian Di Kabupaten Ponorogo. Journal Buana Sains, 15(2), 181-188.

Kurniawan, R., \& Yuniarto, B. (2016). Analisis Regresi: Dasar dan Penerapannya dengan $R$ Edisi Pertama (1st ed.). PT Kharisma Putra Utama.

Majid, R. A. (2015). Analisis FaktorFaktor yang Mempengaruhi Pengungkapan Emisi Gas Rumah Kaca pada Perusahaan Indonesia. Ekonomi Dan Bisnis, 1-43.
Mutlik, muhammad affan al. (2011). Tinjauan Geografis Minat Bertani Anggur di Kota Probolinggo dan Faktor-Faktor Yang Mempengaruhi. Universitas Negeri Surabaya.

Naashir, M., Istiatin, I., \& Hartono, S. (2016). Pengaruh Motivasi, Persepsi Dan Sikap Konsumen Terhadap Keputusan Pembelia Sepeda Motor Pada Dealer Honda Astra Motor Palur. Jurnal Studi Manajemen Organisasi, 13(1), 80. https://doi.org/10.14710/jsmo.v13i1 .13415

Piran, R. D., Pudjiastuti, A. Q., \& Dyanasari, D. (2019). Dinamika Generasi Muda Pertanian dalam Pemilihan Usahatani Tanaman Pangan. Agriekonomika, 7(2), 149. https://doi.org/10.21107/agriekono mika.v7i2.4133

Porajouw, I. O., Loho, I. A. E., Rumagit, I. G. A. J., \& Panurat, S. M. (2014). Faktor-Faktor Yang Mempengaruhi Minat Petani Berusahatani Padi Di Desa Sendangan Kecamatan Kakas Kabupaten Minahasa. Cocos, 4(5).

Prasetyo, A. S., Sumekar, W., Kurniasari, D. A., \& Musabikin, A. (2020). Aktivitas dan Tingkat Partisipasi Anggota dalam Usahatani Ternak Sapi Perah di Kelompok Tani Ternak Rejeki Lumintu Gunungpati, Kota Semarang. Jurnal Agrinika: Jurnal Agroteknologi Dan Agribisnis, 4(2), 186.

https://doi.org/10.30737/agrinika.v4 i2.1053

Suhartini, Y. (2011). Analisis Faktor- 
faktor Yang Mempengaruhi Minat Mahasiswa Dalam Berwiraswasta (Studi Pada Mahasiswa Universitas PGRI Yogyakarta). Akmenika Upy, Vol 7(2), 39-59.

Suparmini, Setyawati, S., \& Sumunar, D. R. S. (2013). Berbasis Kearifan Lokal. Jurnal Penelitian Humaniora, 18(1), 8-22.

Suwandari, A., \& Soetriono, S. (2010). Analisis Kebijakan Kopi Robusta dalam Upaya Meningkatkan Daya Saing Dan Penguatan Revitalisasi Perkebunan. J-Sep, 4(3), 60-76.

Thamrin, S. (2016). Efisiensi Teknis Usahatani Kopi Arabika di Kabupaten Enrekang. IImu Pertanian (Agricultural Science), 18(2), 92.

https://doi.org/10.22146/ipas.9090 